\title{
3D Cytocompatible Composites of PCL/Magnetite
}

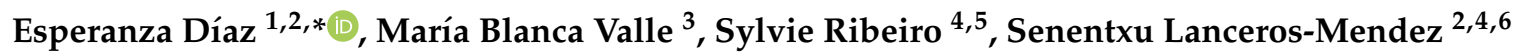 \\ and José Manuel Barandiarán 2,3 \\ 1 Escuela de Ingeniería de Bilbao, Departamento de Ingeniería Minera, Metalúrgica y Ciencia de Materiales, \\ Universidad del País Vasco (UPV/EHU), 48920 Portugalete, Spain \\ 2 BCMaterials, Basque Centre for Materials, Applications and Nanostructures, UPV/EHU Science Park, \\ 48940 Leioa, Spain; senetxu.lanceros@ehu.es (S.L.-M.); jm.barandiaran@ehu.es (J.M.B.) \\ 3 Facultad de Ciencia y Tecnología, Departamento Electricidad y Electrónica, Universidad del País \\ Vasco (UPV/EHU), 48940 Leioa, Spain; mariablanca.valle@ehu.es \\ 4 Centro de Física, Universidade do Minho, 4710-057 Braga, Portugal; sylvie.ribeiro@ehu.es \\ 5 Centre of Molecular and Environmental Biology (CBMA), Universidade do Minho, Campus de Gualtar, \\ 4710-057 Braga, Portugal \\ 6 IKERBASQUE, Basque Foundation for Science, 48013 Bilbao, Spain \\ * Correspondence: esperanza.diaz@ehu.eus; Tel.: +34-66-678-7663
}

Received: 10 October 2019; Accepted: 19 November 2019; Published: 21 November 2019

\begin{abstract}
A study of Magnetite $\left(\mathrm{Fe}_{3} \mathrm{O}_{4}\right)$ as a suitable matrix for the improved adhesion and proliferation of MC3T3-E1 pre-osteoblast cells in bone regeneration is presented. Biodegradable and magnetic polycaprolactone (PCL)/magnetite $\left(\mathrm{Fe}_{3} \mathrm{O}_{4}\right)$ scaffolds, which were fabricated by Thermally Induced Phase Separation, are likewise analyzed. Various techniques are used to investigate in vitro degradation at $37^{\circ} \mathrm{C}$, over 104 weeks, in a phosphate buffered saline (PBS) solution. Magnetic measurements that were performed at physiological temperature $(310 \mathrm{~K})$ indicated that degradation neither modified the nature nor the distribution of the magnetite nanoparticles. The coercive field strength of the porous matrices demonstrated ferromagnetic behavior and the probable presence of particle interactions. The added nanoparticles facilitated the absorption of PBS, with no considerable increase in matrix degradation rates, as shown by the Gel Permeation Chromatography (GPC) results for Mw, Mn, and I. There was no collapse of the scaffold structures that maintained their structural integrity. Their suitability for bone regeneration was also supported by the absence of matrix cytotoxicity in assays, even after additions of up to $20 \%$ magnetite.
\end{abstract}

Keywords: PCL; magnetite; scaffolds; magnetism; cytotoxicity; in vitro degradation

\section{Introduction}

Nanomaterials have attracted increasing scientific interest, due to their numerous biomedical applications. Among such materials, Iron-Oxide NanoParticles (IONPs) awaken special interest, because of their magnetic properties, biocompatibility, and nanometric sizes that can interact at the cellular, subcellular, and even molecular levels $[1,2]$. As iron is a metal that is found in haemoglobin and myoglobin in the form of ferritin, the particles are non-toxic, although particle aggregation can be dangerous [3-5]. Mainly used in biomedicine, IONPs have FDA approval for use in cellular therapy, drug delivery, contrast agents, tumor hyperthermia, and tissue repair. At particle sizes of less than $30 \mathrm{~nm}$, their diameters range between 5 and $100 \mathrm{~nm}$. Each particle produces a nanoscale magnetic field and acts as a single magnetic domain, showing superparamagnetic behavior $[2,6,7]$.

Biodegradable and biocompatible polymers, such as polycaprolactone (PCL), are widely used in biomedical regenerative treatments of hard tissue [8-10], where prolonged degradation times require 
lengthy curing phases [11-15]. PCL scaffolds with lower molecular weights and faster degradation rates are also used in the regenerative treatment of soft tissues, such as cartilage and muscle [12,14].

Therefore, scaffolds have become a key material in tissue engineering, in which various biological agents interact for their correct development $[3,6]$. The manufacture of scaffolds with magnetic fields that attract these biological agents has implied a significant advance. A similar concept was previously used for tumor hyperthermia and the administration of pharmaceuticals $[7,14-16]$. Therefore, magnetic nanoparticles and scaffolds are promising alternatives for bone regeneration. The magnetic fields of the scaffolds function by attracting and absorbing stem cells, in vivo growth factors, and other bioactive agents tied to magnetic particles, favoring bone regeneration and repair [17-23].

There are two methods for the manufacture of magnetic scaffolds: one consists of submerging a scaffold in water-based ferrofluids that contain IONPs through capillary adsorption, as described by other authors [6,19]. The other method involves the incorporation of IONPs during scaffold preparation, a method that requires effective ultrasonic nanoparticle dispersion, to prevent agglomeration [20-27].

A simple and efficient method of incorporating IONP in a scaffold that is manufactured by lyophilization will be presented in this study, so the scaffold magnetization process will not affect the external structure of the scaffold. An in vitro degradation study of the scaffolds manufactured with this method will also be performed. In addition, the utility of these magnetic scaffolds will be demonstrated in a cytotoxicity evaluation of samples with the MC3T3-E1 pre-osteoblast cell line for bone regeneration.

\section{Experimental}

\subsection{Materials}

PCL polymer, which was supplied by Purac Biomaterials Purasorb PCL 12 (Gorinchem, Amsterdam, the Netherlands), was purified by dissolution in 1,4-dioxane (Panreac p.a. Barcelona, Spain). 1,4-Dioxane was used as a solvent. The values of $\mathrm{Mw}=134,418, \mathrm{Mn}=92,103$, and polydispersity $\mathrm{Mw} / \mathrm{Mn}=1.459$ were performed while using gel permeation chromatography (GPC, Perkin Elmer 200, Bridgeport, CT, USA) in tetrahydrofuran (THF). The PBS (phosphate buffer solution) used in the in vitro degradation was supplied by Fluka Analytical (Sigma-Aldrich, Darmstadt, Hessen, Germany) at a $\mathrm{pH}$ of 7.2. The magnetite nanoparticles were supplied by Sigma-Aldrich), CAS Number 1317-61-9, the particle size $\approx 50 \mathrm{~nm}$.

\subsection{Fabrication of Porous Matrices}

Pure PCL and PCL/ $/ \mathrm{Fe}_{3} \mathrm{O}_{4}$ composite scaffolds were made by Thermally-Induced Phase Separation (TIPS) and then by a freeze-drying technique. In brief, a solution of PLLA in 1,4-Dioxane $(2.5 \%(\mathrm{w} / \mathrm{v}))$. Subsequently, magnetite particles (in solid state) were homogeneously blended, in proportions of 5 and $10 \%$ of total polymer mass, by ultrasonic stirring. The solutions were frozen and freeze-dried (LyoQuest of Telstar, Barcelona, Spain) for seven days for the complete elimination of the 1,4 dioxane.

\subsection{In vitro Degradation}

For the degradation test, the porous matrices were cut into $0.5 \mathrm{~cm}^{2}$ rectangular section, weighed, immersed in tubes with $15 \mathrm{~mL}$ of PBS, and then incubated in a thermostated oven at $37^{\circ} \mathrm{C}$. The pieces were recovered after 5, 8, 10, 16, 20, 25, and 28 weeks and then wiped. A pH meter PCE228 (PCE Instruments, Palm Beach, FL, USA) was used to determine the $\mathrm{pH}$ changes in the PBS.

Water absorption $\left(\mathrm{W}_{\mathrm{a}}\right)$ and mass loss $\left(\mathrm{W}_{\mathrm{L}}\right)$ were respectively calculated by the following equations:

$$
\begin{aligned}
& \mathrm{W}_{\mathrm{a}} \%=\frac{\mathrm{Ww}-\mathrm{Wr}}{\mathrm{Wr}} \times 100 \% \\
& \mathrm{~W}_{\mathrm{L}} \%=\frac{\mathrm{Wo}-\mathrm{Wr}}{\mathrm{Wo}_{\mathrm{o}}} \times 100 \%
\end{aligned}
$$


where, $\mathrm{W}_{0}$ is the original weight, $\mathrm{W}_{\mathrm{r}}$ is the residual weight after degradation and when completely dried, and $W_{W}$ is the weight of the sample without surface water.

\subsection{Magnetic Analysis}

A Vibrating Sample Magnetometer (VSM) that was developed at the University of the Basque Country was used for magnetic measurements at physiological temperature (310 K). Pure nickel was used to calibrate the VSM. The magnetic field range was \pm 1.8 Tesla (18 kG) and the resolution \pm 20 $\mu$ Tesla $(0.2 \mathrm{G})$.

\subsection{SEM Analysis}

The morphology of the porous matrices was examined while using scanning electron microscopy (SEM) (HITACHI S-4800, Tokyo, Japan). Before the analysis, a JEL Ion Sputter JFC-1100 (Amiron Machinery, Oxnard, CA, USA) at $1200 \mathrm{~V}$ and $5 \mathrm{~mA}$ was used to coat with a cape of gold.

\subsection{Differential Scanning Calorimetry (DSC)}

DSC assays were made with a Q200 TA Instruments. A nitrogen purge gas was used to avoid any oxidation of the scaffolds during the experiments. These were repeated three times. In the first scan, the scaffolds were heated from -20 to $250^{\circ} \mathrm{C}$ at a rate of $10^{\circ} \mathrm{C} \cdot \mathrm{min}^{-1}$ to record the melting temperature, $\mathrm{Tm}$, and the melting heat, $\Delta \mathrm{H}_{\text {melt }}$. Subsequently, cooled at $10^{\circ} \mathrm{C} \cdot \mathrm{min}^{-1}$ to obtain the glass transition, $\mathrm{T}_{\mathrm{g}}$, and then finally heated at $10^{\circ} \mathrm{C} / \mathrm{min}$. Crystallinity, $\mathrm{X}_{\mathrm{c}}$, was calculated with the following equation:

$$
\mathrm{X}_{\mathrm{c}}(\%)=\left(\Delta \mathrm{H}_{\text {melt }}-\Delta \mathrm{H}_{\text {crystallization }}\right) / \Delta \mathrm{H}_{100 \%} \times 100 \%
$$

$\Delta \mathrm{H}_{\text {melt }}\left(\mathrm{J} \cdot \mathrm{g}^{-1}\right.$ of the crystalline polymer) is the enthalpy of fusion of the sample and $\Delta \mathrm{H}_{100 \%}$ is the enthalpy of fusion of a 100\% crystalline polymer, which for PCL was $139.5 \mathrm{~J} \cdot \mathrm{g}^{-1}$ [24]. The crystallizable fraction $(\mathrm{CF} \%)$ of the samples was calculated with the following equation:

$$
\mathrm{CF} \%=\left(\Delta \mathrm{H}_{\mathrm{c}} / \Delta \mathrm{H}_{\mathrm{m}}\right) \times 100 \%
$$

\subsection{Fourier-Transform Infrared (FTIR) Spectroscopy}

A Thermonicolet Avatar 370 Fourier-transform infrared (FTIR, Thermo Electron Corporation, Waltham, MA, USA) spectrophotometer that was equipped with an attenuated total reflectance attachment with ZnSe crystal was used to make the infrared spectra.

\subsection{Cytotoxicity Assay}

Membrane sterilization: For the in vitro assays, the membranes were cut with $0.1 \mathrm{mg} \cdot \mathrm{mL}^{-1}$ following an adaptation of the ISO 10993-5:2009 (third edition) standard test method (indirect cytotoxicity evaluation). The samples were sterilized by UV ( $1 \mathrm{~h}$ each side). After that, each sample was washed five times ( 5 min each wash) in phosphate buffered saline (PBS) solution.

Cytotoxicity process: The samples were immersed in a 24-well tissue culture polystyrene plate with DMEM obtaining like this a conditioned medium. This medium contains $1 \mathrm{~g} \cdot \mathrm{L}^{-1}$ glucose (Gibco) that was supplemented with 10\% FBS (Biochrom) and 1\% P/S (Biochrom) (basal medium). The plate was incubated for $24 \mathrm{~h}$ at $37{ }^{\circ} \mathrm{C}$, in a $95 \%$ humidified atmosphere containing $5 \% \mathrm{CO}_{2}$. In parallel, the MC3T3-E1 cells, Sigma-Aldrich (Darmstadt, Hessen, Germany) (passage number: 36, Riken bank) were seeded in the 96-well tissue culture polystyrene plate at a density of $3 \times 10^{4}$ cells $\cdot \mathrm{mL}^{-1}$ and then incubated for cell plate attachment $(24 \mathrm{~h})$.

Thereafter, the culture medium from the 96-well tissue culture polystyrene plate was removed and $100 \mu \mathrm{L}$ of conditioned medium was added to the wells incubating for 24 and $72 \mathrm{~h}$. 3-(4,5-dimethylthiazol-2-yl)-2,5-diphenyltetrazolium bromide (MTT) assay was used to quantify the viable cells. In this method, it was used a positive control $(20 \%$ solution of dimethylsulfoxide 
(DMSO, Sigma Aldrich)) and a negative control (cell culture fresh basal medium) to compare with the values that were obtained for the samples in study.

Likewise, the conditioned medium was removed from each well at the end of each cycle (24 and $72 \mathrm{~h}$ ) and the MTT solution (5 $\mathrm{mg} \cdot \mathrm{mL}^{-1}$ in PBS dissolved in DMEM in proportion of $10 \%$ ) was added to the cells. The incubation was done for $2 \mathrm{~h}$ in the dark at $37^{\circ} \mathrm{C}$. After the intended contact time, it was added $100 \mu \mathrm{L}$ of DMSO/well to dissolve the obtained MTT crystals after removing the medium. In the final, microplate reader at $570 \mathrm{~nm}$ was used to measure optical density

All the quantitative results were obtained from four replicates samples and controls and they were analyzed as the average of viability \pm standard deviation (SD).

\section{Results and Discussion}

In this section, the results are presented of the in vitro degradation of the magnetic scaffolds that were manufactured with PLC incorporating magnetized particles of $\mathrm{nFe}_{3} \mathrm{O}_{4}$.

\subsection{Magnetism}

The hysteresis loops of both the $\mathrm{Fe}_{3} \mathrm{O}_{4}$ nanoparticles and of the $\mathrm{PCL} / \mathrm{nFe}_{3} \mathrm{O}_{4}$ scaffolds are shown to be normalized to the $\mathrm{nFe}_{3} \mathrm{O}_{4}$ content in Figure 1a for selected measurements. Magnetic parameters that cover magnetization measured at $1.5 \mathrm{~T}$ (close to saturation), the coercive field $\left(\mu_{0} \mathrm{H}_{\mathrm{c}}\right)$, and the recalculated content of nanoparticles are summarized in Table 1 , as the average of several measurements for each composition (typically three or four samples each). Errors have been estimated as a combination from the standard deviation of the measurements and the absolute accuracy of the instruments and they are always around $2 \%$ of the averaged value. As can be seen, the coercivity of the isolated particles and scaffolds is quite similar. Pure magnetite coercivity $\approx 12 \mathrm{mT}(\approx 120 \mathrm{G})$ is high enough to discount classic superparamagnetic behavior. Therefore, the nanoparticle magnetic properties might be due to strong inter-particular interaction [27] or to the true ferromagnetic state, while considering that their sizes (diameters over $30 \mathrm{~nm}$ ) are within the single domain region.

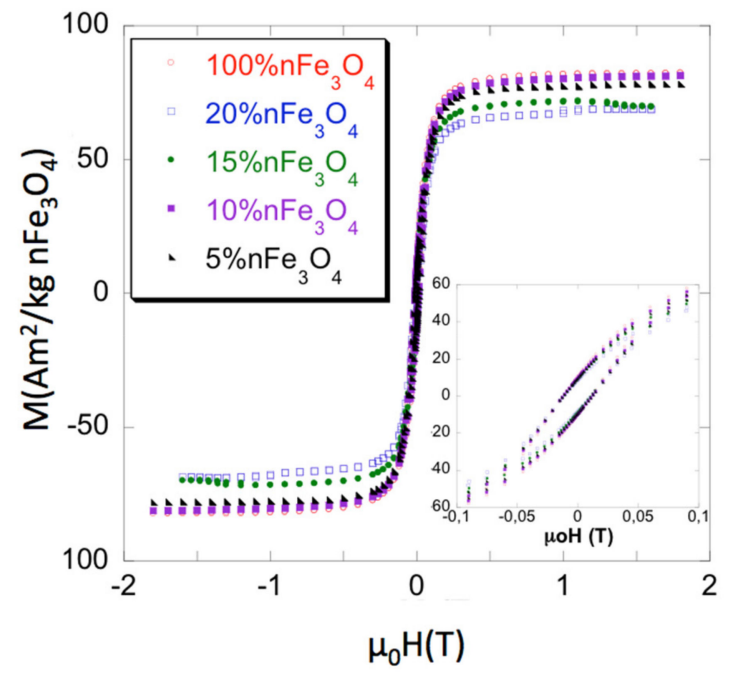

(a)

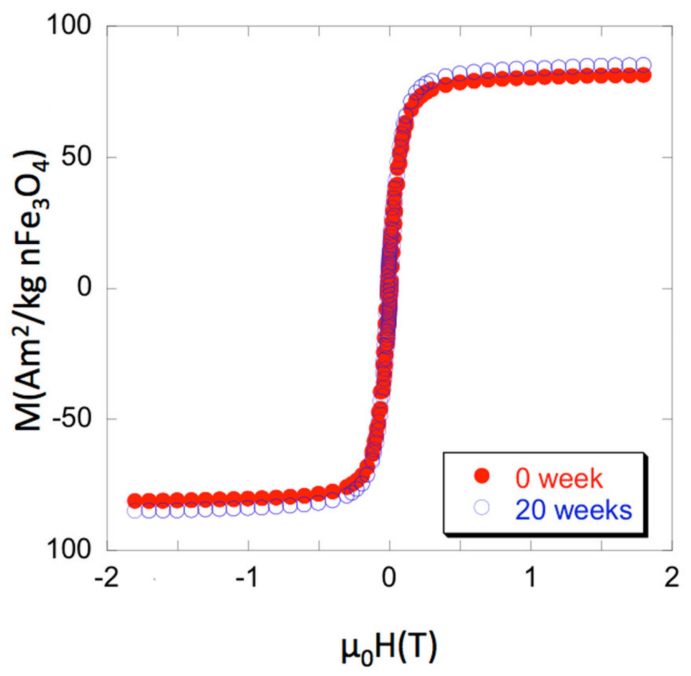

(b)

Figure 1. (a) Magnetization curves of PCL- $\mathrm{nFe}_{3} \mathrm{O}_{4}$. (b) Magnetization curves of PCL- $10 \% \mathrm{nFe}_{3} \mathrm{O}_{4}$ before and after 20 weeks degradation. 
Table 1. Magnetization at 1.5 Tesla relative to the nominal content of $\mathrm{nFe}_{3} \mathrm{O}_{4}$, coercive field, and actual content of $\mathrm{nFe}_{3} \mathrm{O}_{4}$ recalculated from the measurements. Estimated errors are displayed in brackets and refer to the variation of the last significative figure.

\begin{tabular}{cccc}
\hline $\begin{array}{c}\text { \% } \mathrm{nFe}_{3} \mathrm{O}_{4} \\
\text { Nominal }\end{array}$ & $\begin{array}{c}\text { Magnetization at 1.5T } \\
\left(\mathrm{Am}^{2} / \mathbf{k g}_{\mathbf{n F e 3 O}}\right)\end{array}$ & $\begin{array}{c}\boldsymbol{\mu}_{\mathbf{0}} \mathbf{H}_{\mathbf{c}} \\
(\mathbf{m T})\end{array}$ & $\begin{array}{c}\text { \% } \\
\text { Recalculated }\end{array}$ \\
\hline $100^{*}$ & $82(2)$ & $11.9(2)$ & - \\
5 & $78(2)$ & $12.0(2)$ & $4.8(1)$ \\
10 & $81(2)$ & $11.9(2)$ & $9.9(2)$ \\
15 & $75(1)$ & $11.1(2)$ & $13.8(3)$ \\
20 & $69(1)$ & $11.4(2)$ & $16.8(4)$ \\
\hline
\end{tabular}

${ }^{*}$ Pure $\mathrm{nFe}_{3} \mathrm{O}_{4}$ serving as a reference.

Strong interaction within the scaffolds appears to be a less likely hypothesis, as the different $\mathrm{Fe}_{3} \mathrm{O}_{4}$ concentrations caused no changes of coercivity. Particulate interactions can be short or long range: i.e., boundary exchanges or dipolar interactions, respectively. The latter can favor agglomerations, which leads to increased coercivity, by promoting exchange coupling within the agglomerates. Nevertheless, agglomerates are not seen in the microscopy studies, which suggest the good particulate dispersion at all concentrations, with low dispersion of inter-particle distances for each sample. Figure $1 \mathrm{~b}$ shows the effect of 20 weeks degradation on the scaffolds PCL- $10 \% \mathrm{nFe}_{3} \mathrm{O}_{4}$. Both curves, before and after, are superimposed, which indicated that polymer degradation neither affected the characteristics nor the distribution of the magnetic nanoparticles.

\subsection{FTIR}

The FTIR technique characterizes the samples that were subjected to degradation and those that have not been degraded. The characterization through FTIR of the porous substrates composed of PCL- $\mathrm{nFe}_{3} \mathrm{O}_{4}$ (see Figure 2) indicated no interaction between both materials, so the magnetic nanoparticles must therefore be scattered throughout the scaffold structure.

The typical vibration bands of $\mathrm{C}=\mathrm{O}$ and the stretching vibration bands of $\mathrm{C}-\mathrm{O}$ to $1725 \mathrm{~cm}^{-1}$ and to $1293 \mathrm{~cm}^{-1}$, respectively, as well as the symmetric and asymmetric modes of $\mathrm{CH}_{2}$, at $2923 \mathrm{~cm}^{-1}$ and at $2940 \mathrm{~cm}^{-1}$, respectively, refer to the polymer (PCL).

A band of $\mathrm{H}_{2} \mathrm{O}$ located above $3420 \mathrm{~cm}^{-1}$ was observed that grew in strength when increasing the amount of magnetite; a characteristic vibration band of the $\mathrm{Fe}-\mathrm{O}$ bond, hardly perceived in the compositions of 5 and $10 \% \mathrm{nFe}_{3} \mathrm{O}_{4}$, became clearer in the PCL- $\mathrm{nFe}_{3} \mathrm{O}_{4}$ scaffolds containing a higher magnetite content; see Figure 2.

The hydrophilic nature of the system was reflected by the appearance of broad peaks revealing the presence of hydroxyl groups around $3420 \mathrm{~cm}^{-1}$ (Figure 2) for all compositions. These bands indicated the presence of water in the system, despite the lyophilization process.

In Figure $3 \mathrm{a}, \mathrm{b}$, the spectra of both PCL-5\% $\mathrm{nFe}_{3} \mathrm{O}_{4}$ and PCL- $10 \% \mathrm{nFe}_{3} \mathrm{O}_{4}$ were observed after 0,8 , 20 , and 25 weeks of degradation, in which no appreciable signs of degradation were noted, due to the existence of the broad band corresponding to the hydroxyl groups at around $3420 \mathrm{~cm}^{-1}$, which might hide the appearance of a band between 2800 and $3600 \mathrm{~cm}^{-1}$ attributable to a stretching vibration of the $\mathrm{OH}$ bands of the $\mathrm{COOH}$ and $\mathrm{OH}$ groups. Neither can an increase in the intensity be observed in the region of 1100-1050 $\mathrm{cm}^{-1}$. Both of the changes would be due to the scission of the polymeric chains through the ester band, producing a carboxylic group and an alcohol group, as a consequence of the degradation of the PCL. 


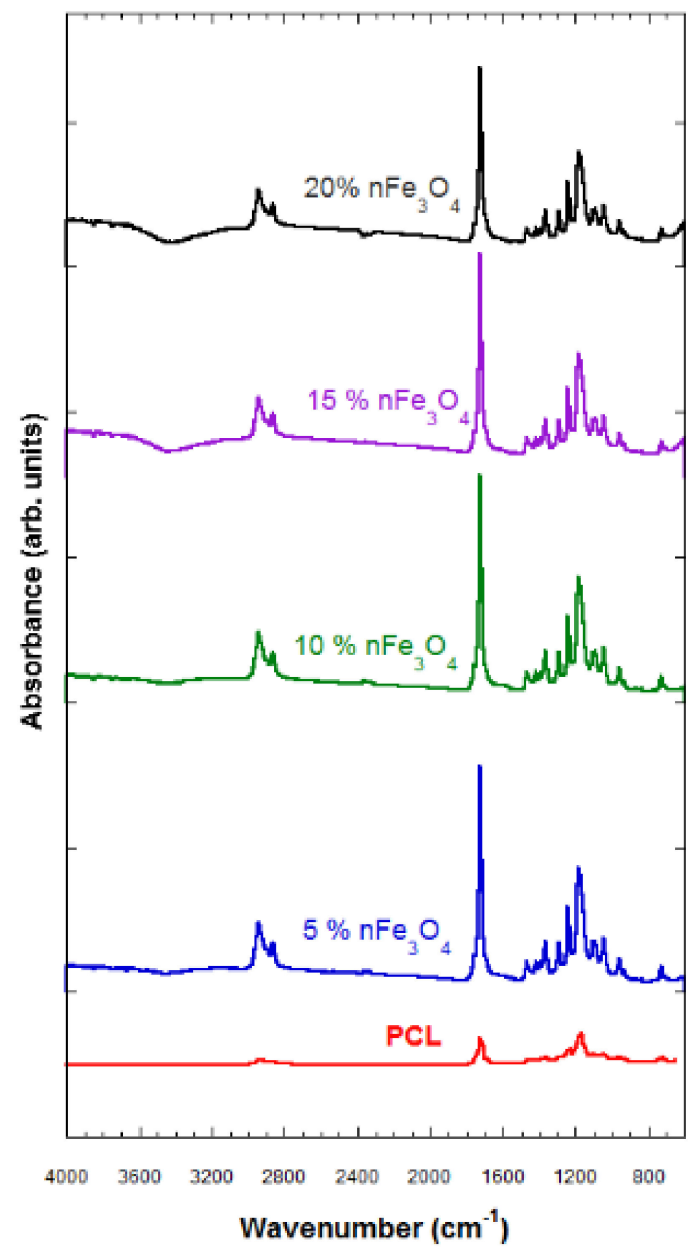

Figure 2. Fourier-Transform Infrared (FTIR) spectra of PCL-n $\mathrm{Fe}_{3} \mathrm{O}_{4}$.

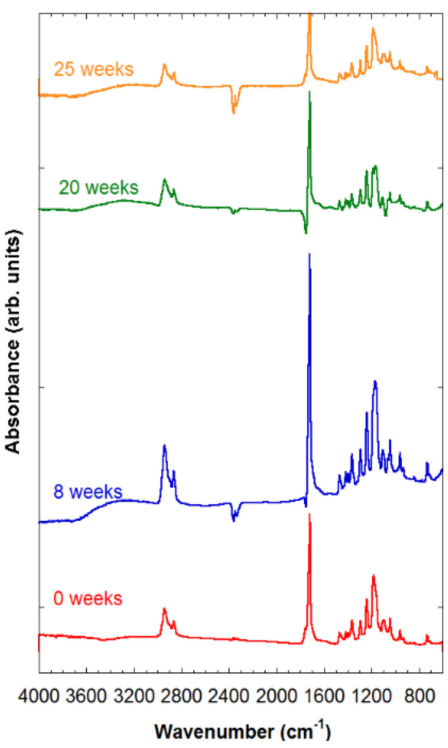

(a)

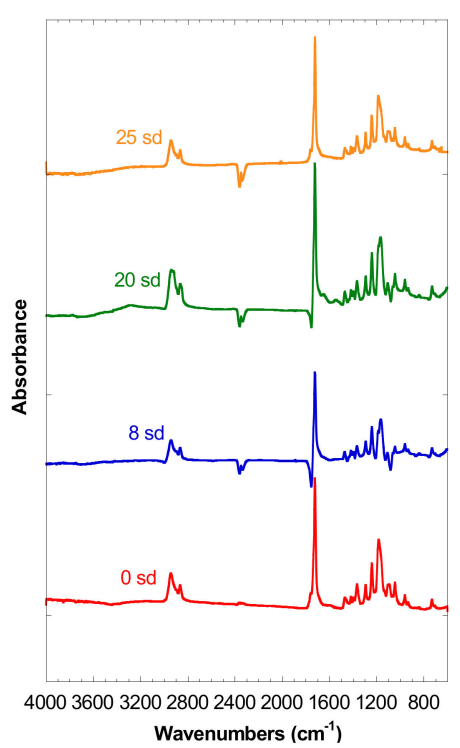

(b)

Figure 3. (a) Spectra of PCL-5\% $\mathrm{nFe}_{3} \mathrm{O}_{4}$ after various degradation times. (b) FTIR spectra of PCL-10\% $\mathrm{nFe}_{3} \mathrm{O}_{4}$ after various degradation times. 


\section{3. $D S C$}

Table 2 shows the values of the characteristic glass-transition temperatures, $T_{g}$, and fusion temperature $\left(\mathrm{T}_{\mathrm{m}}\right)$, as well as the fusion enthalpies $\left(\Delta \mathrm{H}_{\mathrm{m}}\right)$, and crystallization $\left(\Delta \mathrm{H}_{\mathrm{c}}\right)$, and the degree of crystallinity. The $\mathrm{T}_{\mathrm{g}}$ temperature of the $\mathrm{PCL}-\mathrm{nFe}_{3} \mathrm{O}_{4}$-porous scaffolds, $-59{ }^{\circ} \mathrm{C}$, was close to the values cited by other authors for PCL $\left(\sim-60^{\circ} \mathrm{C}\right)$.

Table 2. Parameters obtained by DSC on the PCL-nFe $\mathrm{O}_{4}$ scaffolds: $\mathrm{Tm}=$ melting point $\left({ }^{\circ} \mathrm{C}\right), \Delta \mathrm{H}_{\mathrm{m}}=$ melting enthalpy $(\mathrm{kJ} / \mathrm{kg}), \mathrm{Tc}=$ crystallization temperature $\left({ }^{\circ} \mathrm{C}\right), \Delta \mathrm{H}_{\mathrm{C}}=$ crystallization enthalpy $(\mathrm{kJ} / \mathrm{kg})$, $\mathrm{T}_{\mathrm{g}}=$ glass transition temperature $\left({ }^{\circ} \mathrm{C}\right), \mathrm{X}_{\mathrm{C}}=$ crystalline fraction $(\%)$, calculated as $\mathrm{X}_{\mathrm{C}} \%=\left[\left(\Delta \mathrm{H}_{\mathrm{m} 1}-\right.\right.$ $\left.\left.\Delta \mathrm{H}_{\mathrm{c}}\right) / \Delta \mathrm{H}_{\mathrm{mo}}\right] \times 100 \%$ with $\Delta \mathrm{H}_{\mathrm{mo}}=139.5 \mathrm{~J} \cdot \mathrm{g}^{-1}, \mathrm{CF} \%=\left(\Delta \mathrm{H}_{\mathrm{c}} / \Delta \mathrm{H}_{\mathrm{m} 1}\right) \times 100 \%$.

\begin{tabular}{|c|c|c|c|c|c|c|c|c|c|}
\hline \multirow{2}{*}{$\begin{array}{c}\text { Sample } \\
\text { PCL } \\
\text { dt (weeks) }\end{array}$} & \multicolumn{2}{|c|}{ 1st Run } & \multicolumn{2}{|c|}{ 2nd Run } & \multicolumn{2}{|c|}{ 3rd Run } & \multirow[b]{2}{*}{$\mathrm{T}_{\mathrm{g}}\left({ }^{\circ} \mathrm{C}\right)$} & \multirow[b]{2}{*}{$X_{c} \%$} & \multirow[b]{2}{*}{$\mathrm{CF} \%$} \\
\hline & $\begin{array}{l}\mathrm{T}_{\mathrm{m} 1} \\
\left({ }^{\circ} \mathrm{C}\right)\end{array}$ & $\begin{array}{l}\Delta \mathbf{H}_{\mathrm{m} 1} \\
\left(\mathrm{~J} \cdot \mathrm{g}^{-1}\right)\end{array}$ & $\begin{array}{c}\mathrm{T}_{\mathrm{c}} \\
\left({ }^{\circ} \mathrm{C}\right)\end{array}$ & $\begin{array}{c}\Delta \mathbf{H}_{\mathrm{c}} \\
\left(\mathrm{J} \cdot \mathrm{g}^{-1}\right)\end{array}$ & $\begin{array}{l}\mathrm{T}_{\mathrm{m} 2} \\
\left({ }^{\circ} \mathrm{C}\right)\end{array}$ & $\begin{array}{l}\Delta \mathrm{H}_{\mathrm{m} 2} \\
\left(\mathrm{~J} \cdot \mathrm{g}^{-1}\right)\end{array}$ & & & \\
\hline $0 \% \mathrm{nFe}_{3} \mathrm{O}_{4}$ & 60 & 107.4 & 26 & 64.7 & 57 & 83.2 & -59 & 77 & 60.2 \\
\hline $5 \% \mathrm{nFe}_{3} \mathrm{O}_{4} 0 \mathrm{dt}$ & 60 & 94.6 & 30 & 60.2 & 58 & 74.1 & -59 & 68 & 64 \\
\hline $4 \mathrm{dt}$ & 63 & 93.9 & 31 & 59.2 & 57 & 65.6 & -58.5 & 67 & 63 \\
\hline $8 \mathrm{dt}$ & 64 & 88.7 & 30.5 & 58.6 & 58 & 65.4 & -60 & 64 & 66 \\
\hline $16 \mathrm{dt}$ & 63 & 90 & 30 & 58.1 & 58 & 65.4 & -63 & 65 & 65 \\
\hline $20 \mathrm{dt}$ & 67 & 80.5 & 31.5 & 53 & 56.5 & 72.9 & -63 & 58 & 65 \\
\hline $25 \mathrm{dt}$ & 67 & 77.7 & 31 & 52.4 & 56 & 68.5 & -63 & 56 & 67 \\
\hline $104 \mathrm{dt}$ & 65 & 90.2 & 31 & 57.4 & 58 & 59.7 & -64 & 65 & 64 \\
\hline $10 \% \mathrm{nFe}_{3} \mathrm{O}_{4} 0 \mathrm{dt}$ & 59 & 92.2 & 31 & 59.9 & 56 & 73.6 & -59 & 66 & 65 \\
\hline $4 \mathrm{dt}$ & 63 & 67 & 31 & 47.2 & 57.5 & 49 & -58 & 48 & 70 \\
\hline $8 \mathrm{dt}$ & 64 & 91 & 31 & 59.3 & 58 & 66.9 & -61 & 65 & 65 \\
\hline $16 \mathrm{dt}$ & 63 & 80.2 & 31 & 49.7 & 58 & 64.4 & -58 & 57 & 62 \\
\hline $20 \mathrm{dt}$ & 66 & 77.5 & 30.5 & 49.4 & 55.5 & 57.6 & -63 & 56 & 62 \\
\hline $25 \mathrm{dt}$ & 67 & 76.9 & 32 & 48 & 56 & 54.7 & -63 & 55 & 62 \\
\hline $104 \mathrm{dt}$ & 65 & 94.3 & 31 & 55.4 & 57 & 62.2 & -63 & 68 & 59 \\
\hline $15 \% \mathrm{nFe}_{3} \mathrm{O}_{4} 0 \mathrm{dt}$ & 59 & 83.1 & 30 & 52 & 59 & 69.7 & -58 & 60 & 63 \\
\hline $20 \% \mathrm{nFe}_{3} \mathrm{O}_{4} 0 \mathrm{dt}$ & 58 & 81.3 & 30 & 51 & 58 & 65.9 & -58 & 58 & 63 \\
\hline
\end{tabular}

Even though PCL is a hydrophobic polymer, the presence of magnetite nanoparticles that were embedded in the polymeric matrix make the surface hydrophilic rather than hydrophobic, improving its biocompatibility through intramolecular bridging interactions, and hydrogen bonds. However, the addition of nanoparticles modified the polymer, reducing the degree of crystallinity $\left(\mathrm{X}_{\mathrm{C}} \%\right)$ of the PCL, which passed from a value of $77 \%$ in the scaffolds of pure polymer, to $55 \%$ in PCL-20\% $\mathrm{nFe}_{3} \mathrm{O}_{4}$, indicating that the magnetite nanoparticles played no role as nucleation agents [28].

The $\mathrm{T}_{\mathrm{c}}$ (crystallization temperature) notably increased with the addition of the nanoparticles, which entailed a much slower crystallization process of the PCL- $\mathrm{nFe}_{3} \mathrm{O}_{4}$ scaffolds, thereby confirming that the nanoparticles were not acting as nucleating agents. $\Delta \mathrm{H}_{\mathrm{m}}$ clearly diminished with the increased concentration of nanoparticles, from $107 \mathrm{~J} \cdot \mathrm{g}^{-1}$ to $81 \mathrm{~J} \cdot \mathrm{g}^{-1}$, in the pure PCL and in the PCL with a content of $20 \% \mathrm{nFe}_{3} \mathrm{O}_{4}$, respectively.

The samples with a higher content of nanoparticles presented lower crystallinity and fusion enthalpies, due to the increased rigidity of the polymeric chains [28,29], which was clearly evident from both the crystallinity percentages and the $\mathrm{T}_{\mathrm{g}}$.

During the degradation process, the $T_{\mathrm{g}}$ fell to temperatures lower than $-59{ }^{\circ} \mathrm{C}$ in week 0 to $-63{ }^{\circ} \mathrm{C}$ in week 104 for both series of compound materials. Other authors have observed this same diminishment of $\mathrm{T}_{\mathrm{g}}$ in relation to the in-vitro degradation [30].

The degree of crystallinity of these samples hardly varied over the time of immersion. In addition, a stretching might be seen in the fusion temperature interval for week 25 in both compositions. 
In Figure $4, \mathrm{~T}_{\mathrm{m} 1}$ can be seen to gain a much higher temperature of $65^{\circ} \mathrm{C}$ for both compositions for week 104 of degradation and, at the same time, has a broad endothermic peak. This behavior is indicative of crystallites of different sizes, a form of degradation in which polymeric chains of different lengths are produced that are characterized by their different fusion temperatures. The shortening of the polymeric chains was unrelated to increased crystallinity. In any case, the presence of polymeric chains of different lengths makes it clear that heterogeneous degradation took place at this stage [31].

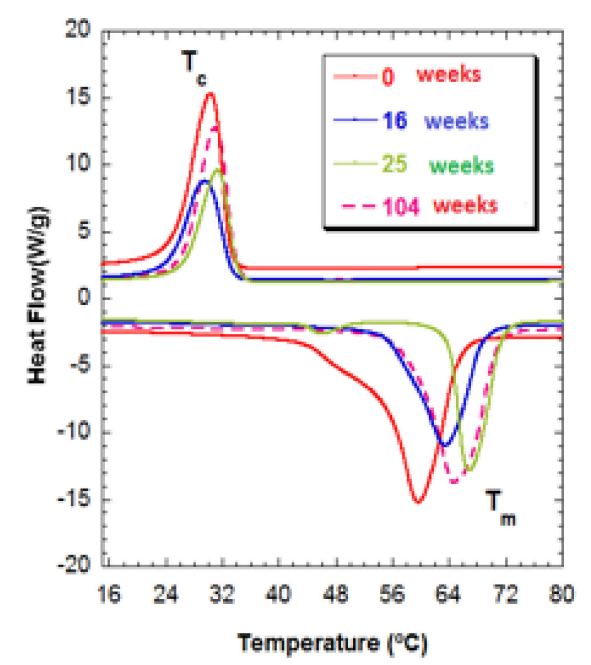

(a)

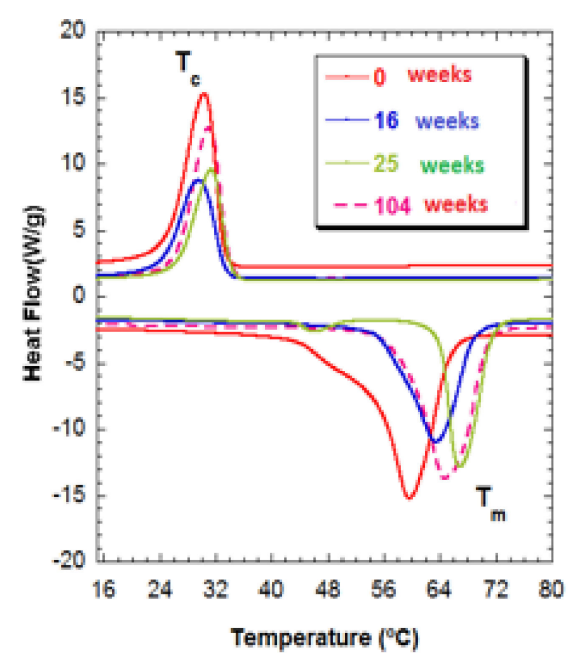

(b)

Figure 4. (a) Thermograms of PCL-5\% $\mathrm{nFe}_{3} \mathrm{O}_{4}$ after various degradation times. (b) Thermograms of PCL-10\% $\mathrm{nFe}_{3} \mathrm{O}_{4}$ after various degradation times.

\subsection{SEM}

In Figure 5, we can observe the magnetite nanoparticles and the PCL scaffold both without mixing. Magnetite nanoparticles were analyzed while using TEM and SEM techniques Figure 1a,b, they are agglomerated and it was very difficult to identify single nanoparticles of $\sim 50 \mathrm{~nm}$, as indicated by the provide.

The matrix manufacturing technique (TIPs) with low percentages of polymer and a volume of solvent created highly porous scaffolds with random pore structures, as may be seen in Figures $5 \mathrm{c}$ and 6. A typical nucleation structure in all of the scaffolds, due to an excessively rapid cooling speed, was obtained, as the solid-liquid phase separation process to take place [32].

We can also see in Figure 6 that the increased content of $\mathrm{nFe}_{3} \mathrm{O}_{4}$ in the composition of the scaffold produced larger-sized pores and thinner walls, acquiring a more scattered appearance and more irregular pore distribution.

Measuring the exact sizes of the pores was not simple, due to the anisotropy of the porosity. In general, the macropores appeared to have average diameters of $\sim 100 \mu \mathrm{m}$ for the composition with $5 \%$ magnetite and $\sim 130 \mu \mathrm{m}$ for the composition with $10 \%$. The diameter of the macropores fluctuated between $25-210 \mu \mathrm{m}$ and the micropore diameter was between $2-10 \mu \mathrm{m}$, for the composition with 5\% magnetite and between 45-250 $\mu \mathrm{m}$, and between 4-15 $\mu \mathrm{m}$, respectively, for the composition with $10 \%$. Both of the compositions presented the typical topographic features of the nucleation mechanism and growth, with large perceptible increases (Figure $6 a, d$ ). The surface of the pore walls contained hill-style structures, with small peaks that gave the walls an appearance of micro-nano ruggedness (marked with green circles in Figure 6a,d) [33]. As the process of in-vitro degradation advanced, the pores both shrank and lengthened (Figure $6 \mathrm{~b}, \mathrm{e}$ ); both of the compositions presented greater microporosity. In the PCL- $5 \% \mathrm{nFe}_{3} \mathrm{O}_{4}$ composition, the gradual appearance of micropores can start to be appreciated in a generalized way on the walls of the scaffold skeletons in week eight of degradation (Figure 6b), 
while in the composition with $10 \% \mathrm{nFe}_{3} \mathrm{O}_{4}$, they were appreciable from week 16 onwards (Figure 6e). The pore walls, rather than not clean and smooth, were rugged, characteristic of the liquid-liquid separation through the nucleation mechanism and growth.

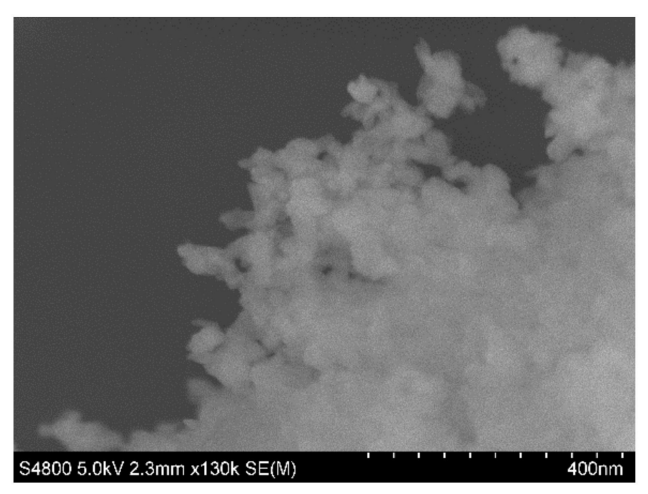

(a)

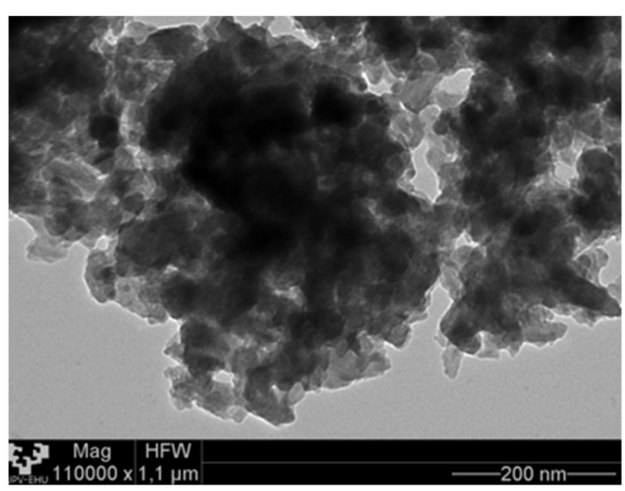

(b)

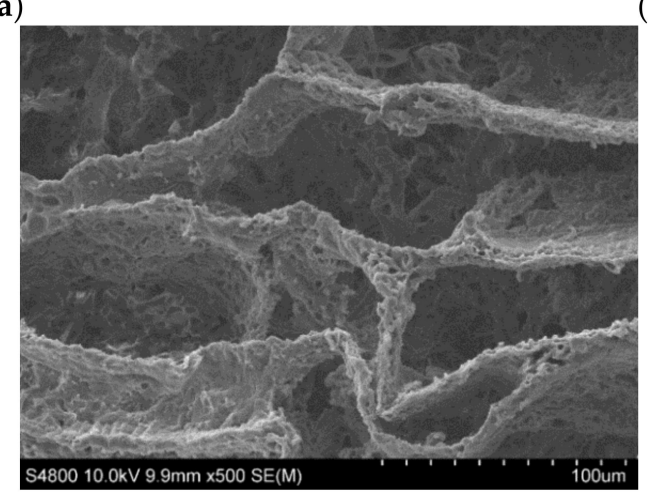

(c)

Figure 5. (a) Scanning electron microscopy (SEM) micrograph of magnetite nanoparticles. (b) TEM micrograph of magnetite nanoparticles. (c) SEM micrograph of poly( $\varepsilon$-caprolactone) (PCL) scaffold.

The magnetite particles were visible at higher magnifications after the degradation process at week 25, as can be clearly seen in Figure 6c (blue circles) for the composition with fewer particles.

While observing Figure $6 c, e$, it may be seen that there were more broken fibers and slightly deteriorated pores in week 25 of degradation: no degradation products were observed. This deterioration process provided the clearest morphological evidence of scaffold degradation, although the structural integrity of the scaffolds was maintained and no collapse of the structure occurred. 

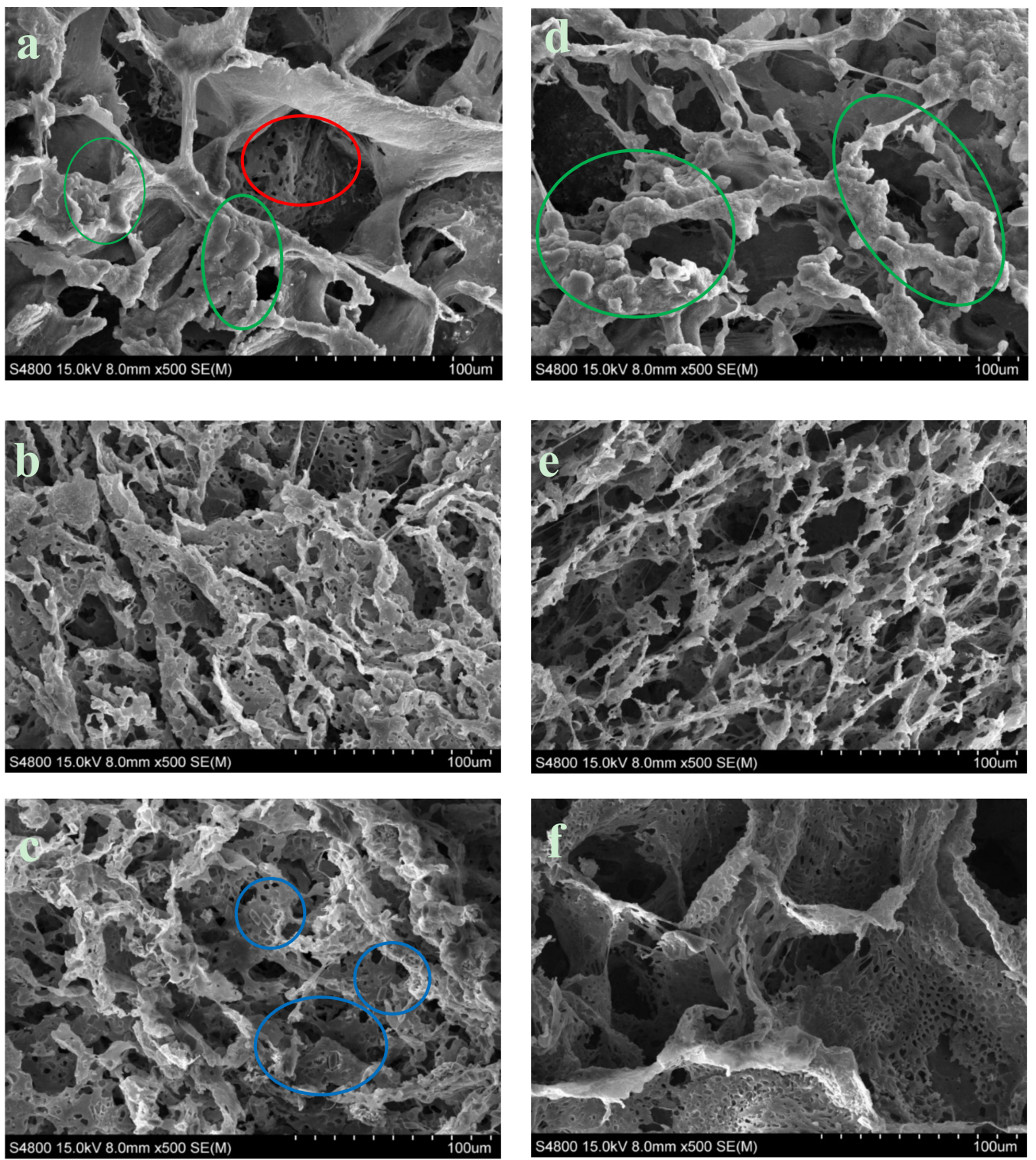

Figure 6. SEM observation of Surface morphology of PCL $\times 500$. (a) PCL-5\% $\mathrm{nFe}_{3} \mathrm{O}_{4}$. (b) PCL-5\% $\mathrm{nFe}_{3} \mathrm{O}_{4}$ after in vitro degradation for 8 weeks. (c) PCL-5\% $\mathrm{nFe}_{3} \mathrm{O}_{4}$ after in vitro degradation for 25 weeks. (d) $\mathrm{PCL}-10 \% \mathrm{nFe}_{3} \mathrm{O}_{4}$. (e) PCL-10\% $\mathrm{nFe}_{3} \mathrm{O}_{4}$ after in vitro degradation for 16 weeks. (f) PCL-10\% $\mathrm{nFe}_{3} \mathrm{O}_{4}$ after in vitro degradation for 25 weeks.

\subsection{Water Absorption}

The measurement of water absorption assisted the evaluation of the porous matrices of the PCL- $\mathrm{nFe}_{3} \mathrm{O}_{4}$ system. Other authors have previously observed a marked decrease in water absorption, which was coincident with a reduction in the mass of the sample and an increase in its dimensions [34,35]. In our study, no swelling of the scaffolds or any dramatic reduction in mass for any composition was observed. However, there were increases in water absorption that may be attributed to the absorption mechanism of PBS. PCL is a highly hydrophobic material and the absorption of water both in the scaffold pores and in the polymeric network was slow. During the first days in PBS, the pores of the scaffolds were filled with both air bubbles and water. The presence of those air bubbles persisted inside the internal scaffold pores, which blocled the penetration of water. As the water content never achieved equilibrium, it varied over time. Therefore, the variation in water absorption without the 
corresponding changes in the mass, the morphology, and/or the thermal properties in no way suggested the degradation of the porous matrices [33-36].

Moreover, the clearly alkaline property of the magnetite nanoparticles has to be considered, which can act as a physical barrier that blocks the entry of water into the scaffold, diminishing the speed of degradation, which can neutralize the degradation products, reducing the autocatalytic degradation of the polymer [36-38].

The curves in Figure 7a show that the scaffolds never absorbed large quantities of PBS during the first five weeks of incubation, after which water absorption slightly fluctuated up until week 12 . As from week 5, it drastically increased up until week 25, especially for the composition with $10 \%$ nanoparticles. This behavior was very different from the one presented by the PCL-nHAFe system [22], which underwent rapid and greater absorption from week 5 .

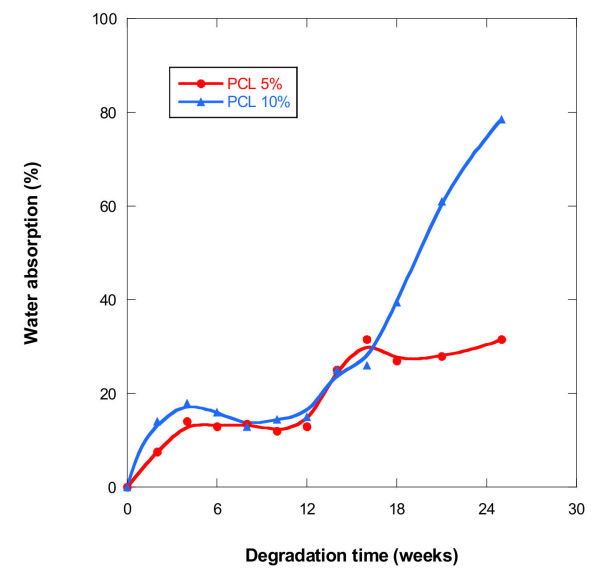

(a)

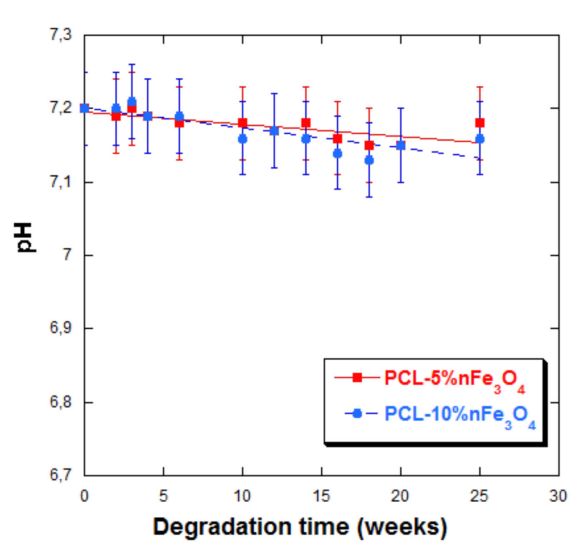

(b)

Figure 7. (a) Water absorption by PCL- $5 \% \mathrm{nFe}_{3} \mathrm{O}_{4}$ and PCL- $10 \% \mathrm{nFe}_{3} \mathrm{O}_{4}$ matrices vs. degradation time; (b) $\mathrm{pH}$ of the PBS solution vs. degradation time.

It was also observed that the higher the content of magnetite nanoparticles in the samples that were subjected to degradation, the higher the quantities of water that they were cable of absorbing, up until week 25, leading to a quicker degradation rate, a behavior that has also been observed by other authors [39]. However, absorption diminished in samples after two years of in-vitro degradation when the quantity of nanoparticles increased.

3.6. $p H$

The $\mathrm{pH}$ of the aqueous medium that varied with degradation time is a measure that indicates the liberation of acidic products, which reflects the advance of the degradation process. In all of the samples under study, a very small but sustained reduction in the $\mathrm{pH}$ (Figure $7 \mathrm{~b}$ ) was observed, except at week 4 of degradation in both scaffolds, when an increase in $\mathrm{pH}$ was observed. The fall in $\mathrm{pH}$ was minimal, due to the basic character of the nanoparticles or because the degradation products were themselves minimal.

\subsection{Mass and Weight Loss}

The in-vitro degradation process implies an alteration in the structure of matrices, which, in turn, means the degradation of the polymeric chain and a decrease in the molecular weight.

Over the first 25 weeks, no mass variation was obtained in the scaffolds with the lowest content of nanoparticles, obtaining a minimal loss of $2 \%$ in week 104 of degradation. Besides, the composition with $10 \% \mathrm{nFe}_{3} \mathrm{O}_{4}$ underwent a slight loss of mass, less than $8 \%$, as from week 14 , with slight fluctuations always below that value throughout the degradation period. 
Table 3 shows the values of Mw (average molecular weight by weight), Mn (average molecular weight by number), and I (polydispersity), which are directly related with the polymer chains and the dispersity of their molecular weights. The introduction of $\mathrm{Fe}_{3} \mathrm{O}_{4}$ nanoparticles evidently delayed the start of the degradation process, due to the slight variation in both the molecular mass and in the molecular weight at week 25 of degradation. As from week 25 of degradation, we can see that the $\mathrm{Mw}$ and the Mn of both samples diminished and the I of 1.459 increased to 1.617, due to the cleavage of the polymer chains that resulted from hydrolysis. In addition, the samples with fewer nanoparticles had a slightly higher I in week 104. The concentration of $\mathrm{nFe}_{3} \mathrm{O}_{4}$ had no great effect on the speed of sample degradation of the samples when they underwent a similar loss in molecular weight $(\mathrm{Mw})$.

Table 3. Molecular weight: weight average (Mw), number average (Mn), and polydispersity index I of the PCL-nFe $\mathrm{O}_{4}$ system.

\begin{tabular}{ccccc}
\hline Sample & Degradation Time (Weeks) & Mw & Mn & I \\
\hline $\mathrm{PCL}$ & 0 & 134418 & 92103 & 1.459 \\
\hline \multirow{2}{*}{$\mathrm{PCL}-5 \% \mathrm{nFe}_{3} \mathrm{O}_{4}$} & 25 & 143410 & 97073 & 1.477 \\
\cline { 2 - 5 } & 104 & 99888 & 61754 & 1.617 \\
\hline \multirow{2}{*}{$\mathrm{PCL}-10 \% \mathrm{nFe}_{3} \mathrm{O}_{4}$} & 25 & 139433 & 90264 & 1.545 \\
\cline { 2 - 5 } & 104 & 86212 & 54070 & 1.594 \\
\hline $\mathrm{PCL}-15 \% \mathrm{nFe}_{3} \mathrm{O}_{4}$ & 0 & 134441 & 95866 & 1.402 \\
\hline
\end{tabular}

\subsection{Cytotoxicity}

A cytotoxicity study of the materials that have been developed is essential for assessing their applicability for biomedical and tissue engineering applications. Thus, the effect of the polymer extract medium on the metabolic activity of MC3T3-E1 pre-osteoblast cells was evaluated while using MTT after 24 and $72 \mathrm{~h}$ (Figure 8).

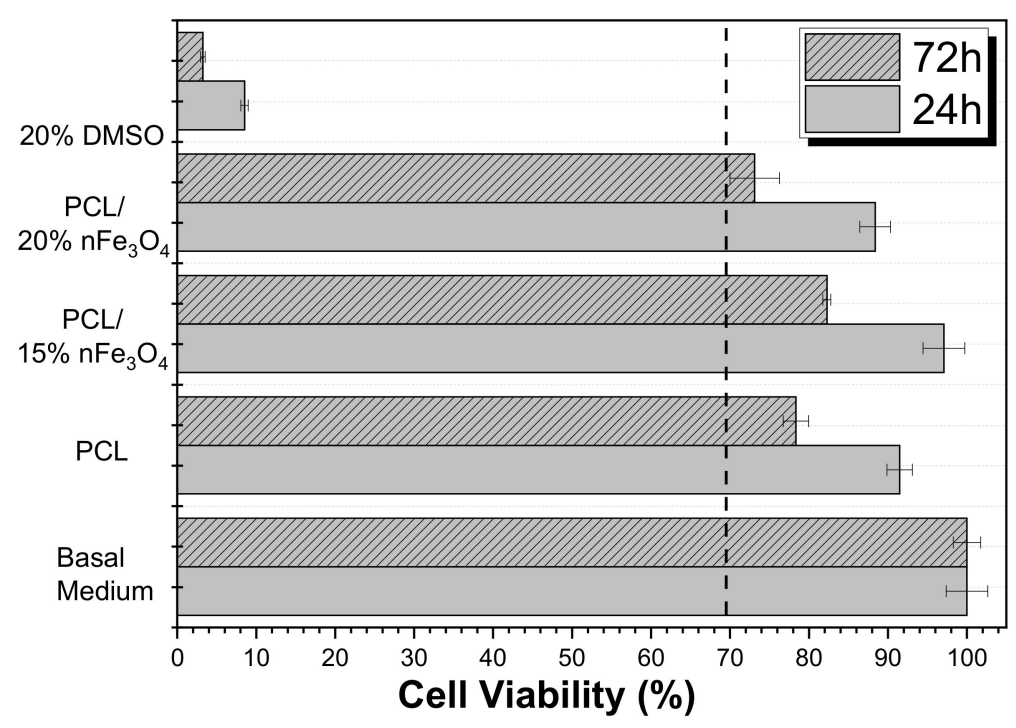

Figure 8. Cell Viability of MC3T3-E1 pre-osteoblast cell line in contact with the conditioned medium exposed with different samples after 24 and $72 \mathrm{~h}$.

The use of poly( $\varepsilon$-caprolactone) (PCL) as a scaffold material is not restricted to one type of tissue due to its adaptability. It is a biocompatible polyester that has been widely used in tissue engineering based on its availability, its relative inexpensiveness, and its suitability for specific modifications [35,37]. Figure 8 shows that neat PCL is non-cytotoxic up to $72 \mathrm{~h}$ (cell viability reduction 
is less than $30 \%$ ), as reported in the literature. According to the ISO standard 10993-5, the samples are only considered to be cytotoxic when the cell viability reduction is more than $30 \%$. Although the $\mathrm{Fe}_{3} \mathrm{O}_{4}$ nanoparticles are cytotoxic at certain concentrations [38], the composites $\mathrm{PCL} / \mathrm{Fe}_{3} \mathrm{O}_{4}$ are non-cytotoxic. Nevertheless, it was noted that the scaffolds with $20 \% \mathrm{Fe}_{3} \mathrm{O}_{4}$ were at the limit of their cytotoxicity. These results showed that the nanoparticles were properly encapsulated within the biocompatible polymer, which agrees with previous studies on related polymers [39-41].

Therefore these materials are reliable alternatives for bone tissue engineering and can also be explored in dynamic cell culture through suitable magnetic stimulation.

\section{Conclusions}

The Thermally Induced Phase Separation (TIPS) method has been shown to be a promising and simple method for the manufacture of porous magnetic matrices of polycaprolactone with magnetite nanoparticles. The addition of nanoparticles facilitated the absorption of PBS, with no greater increase in the degradation speed of the matrices, as demonstrated by the results of $\mathrm{Mw}, \mathrm{Mn}$, and I. The study of matrix morphology through SEM appeared to not point to a degradation process over the period of this study, with the exception of pore size reduction. The size of the nanoparticles determined the ferromagnetic behavior of the scaffolds, which were non-cytotoxic for the MC3T3-E1 pre-osteoblast cells.

Author Contributions: J.M.B., S.L.-M., M.B.V., S.R. and E.D. conceived and designed the experiments; M.B.V. and S.R. performed the experiments; J.M.B., S.L.-M., M.B.V., S.R. and E.D. analyzed the data; J.M.B. and E.D. contributed reagents/materials/analysis tools; E.D. wrote the paper.

Funding: This work was supported by the Spanish Ministry of Economy and Competitiveness (MINECO) through the project MAT2016-76039-C4-3-R (AEI/FEDER, UE) and from the Basque Government Industry Department under the ELKARTEK, HAZITEK and PIBA programs. Supported by the Portuguese Foundation for Science and Technology (FCT) in the framework of the Strategic Funding UID/FIS/04650/2013, project POCI-01-0145-FEDER-028237 and grant SFRH/BD/111478/2015 (S.R.) is acknowledged.

Acknowledgments: Technical and human support provided by SGIker (UPV/EHU, MICINN, GV/EJ, ERDF and ESF) is gratefully appreciated. The authors acknowledge funding by the Spanish Ministry of Economy and Competitiveness (MINECO) through the project MAT2016-76039-C4-3-R (AEI/FEDER, UE) and from the Basque Government Industry and Education Department under the ELKARTEK and HAZITEK and PIBA (PIBA-2018-06) programs. Supported by the Portuguese Foundation for Science and Technology (FCT) in the framework of the Strategic Funding UID/FIS/04650/2013, project POCI-01-0145-FEDER-028237 and grant SFRH/BD/111478/2015 (S.R.) is acknowledged.

Conflicts of Interest: The authors declare no conflicts of interest.

\section{References}

1. Cardoso, V.F.; Francesko, A.; Ribeiro, C.; Bañobre-López, M.; Martins, P.; Lanceros-Mendez, S. Advances in magnetic nanoparticles for biomedical applications. Adv. Healthc. Mater. 2018, 7, 1700845-1700880. [CrossRef] [PubMed]

2. Díaz, E.; Valle, M.B.; Ribeiro, S.; Lanceros-Mendez, S.; Barandiarán, J.M. A New Approach for the fabrication of Cytocompatible PLLA-Magnetite Nanoparticle Composite Scaffold. Int. J. Mol. Sci. 2019, 20, 4664. [CrossRef] [PubMed]

3. Jiang, Z.; Shan, K.; Song, J.; Liu, J.; Rajendran, S.; Pugazhendhi, A.; Jacob, J.A.; Chen, B. Toxicity of iron oxide nanoparticles: Size and coating effects. J. Biochem. Mol. Toxicol. 2018. [CrossRef]

4. Srikanth Vallabani1, N.V.; Singh, S. Recent advances and future prospects of iron oxide nanoparticles in biomedicine and diagnostics. 3 Biotech 2018, 8, 279. [CrossRef]

5. Ramesh, V.; Ravichandran, P.; Copeland, C.L.; Gopikrishnan, R.; Biradar, S.; Goornavar, V.; Ramesh, G.T.; Hall, J.C. Magnetite induces oxidative stress and apoptosis in lung epithelial cells. Mol. Cell. Biochem. 2012, 363, 225-234. [CrossRef]

6. Bock, N.; Riminucci, A.; Dionigi, C.; Russo, A.; Tampieri, A.; Landi, E.; Goranov, V.A.; Marcacci, M.; Dediu, V. A novel route in bone tissue engineering: Magnetic biomimetic scaffolds. Acta Biomater. 2010, 6, 786-796. [CrossRef] 
7. Barry, S.E. Challenges in the development of magnetic particles for therapeutic applications. Int. J. Hyperth. 2008, 24, 451-466. [CrossRef]

8. Woodruff, M.A.; Hutmacher, D.W. Th return of a forgotten polymer-Polycaprolactone in the 21st century. Prog. Polym. Sci. 2010. [CrossRef]

9. Malikmammadov, E.; Tanir, T.E.; Kiziltay, A.; Hasirce, V.; Hasirci, N. PCL and PCL-based materials in biomedical applications. J. Biomater. Sci. Polym. Ed. 2018, 29, 7-9. [CrossRef]

10. Kim, J.J.; Rajendra, K.; Singh, S.; Seo, S.J.; Kim, T.H.; Kim, J.H.; Lee, E.J.; Kim, H.W. Magnetic scaffolds of polycaprolactone with functionalized magnetite nanoparticles: Physicochemical, mechanical, and biological properties effective for bone regeneration. RCS Adv. 2014, 4, 17325-17336. [CrossRef]

11. Malikmammadov, E.; Tanir, T.E.; Kiziltay, A.; Hasirci, V.; Hasirci, N. Permeability and in vivo distribution of poly ( $\varepsilon$-caprolactone) nanoparticles loaded with zidovudine. J. Nanopar. Res. 2018, 20, 176-178.

12. Hao, H.K.; Kuo, C.Y.; Chen, K.S.; Chen, S.P. Preparation of Gelatin and Gelatin/Hyaluronic Acid Cryogel Scaffolds for the 3D Culture of Mesothelial Cells and Mesothelium Tissue Regeneration. Int. J. Mol. Sci. 2019, 20, 4527-4535.

13. Soliman, S.; Pagliari, S.; Rinaldi, A.; Forte, G.; Fiaccavento, R.; Pagliari, F.; Traversa, E. Multiscale three-dimensional scaffolds for soft tissue engineering via multimodal electrospinning. Acta Biomater. 2010, 6, 1227-1237. [CrossRef] [PubMed]

14. Dobson, J. Magnetic nanoparticles for drug delivery. Drug. Dev. Res. 2006, 67, 55-60. [CrossRef]

15. Ito, A.; Shinkai, M.; Honda, H.; Kobayashi, T. Medical application of functionalized magnetic nanoparticles. J. Biosci. Bioeng. 2005, 100, 1-11. [CrossRef]

16. Muthana, M.; Scott, S.D.; Farrow, N.; Morrow, F.; Murdoch, C.; Grubb, S.; Lewis, C.E. A novel magnetic approach to enhance the efficacy of cell-based gene therapies. Gene Ther. 2008, 15, 902-910. [CrossRef]

17. Li, Y.; Ye, D.; Li, M.; Ma, M.; Gu, N. Adaptative Materials Based on Iron Oxide Nanoparticles for Bone regeneration. ChemPhysChem 2018, 19, 1965-1979. [CrossRef]

18. Xia, Y.; Sun, J.; Zhang, F.; Liang, X.J.; Guo, Y.; Weir, M.D.; Reynolds, M.A.; Gu, N.; Xu, H.H.K. Magnetic field and nano-scaffolds with stem cells to enhance bone regeneration. Biomaterials 2018, 183, 151-170. [CrossRef]

19. Sun, J.; Fan, F.G.; Wang, P.; Ma, S.Y.; Song, L.N.; Gu, N. Orientation-Dependent Thermogenesis of Assembled Magnetic Nanoparticles in the Presence of an Alternating Magnetic Field. ChemPhysChem 2016, 17, 3377-3384. [CrossRef]

20. Lee, M.S.; Su, C.M.; Yeh, J.C.; Wu, P.R.; Tsai, T.Y.; Lou, S.L. Synthesis of composite magnetic nanoparticles $\mathrm{Fe}_{3} \mathrm{O}_{4}$ with alendronate for osteoporosis treatment. Int. J. Nanomed. 2016, 11, 4583-4594. [CrossRef]

21. Usov, N.A.; Gudoshnikov, S.A.; Serebryakova, O.N.; Fdez-Gubieda, M.L.; Muela, A.; Barandiaran, J.M. Properties of dense assemblies of magnetic nanoparticles romising for application in biomedicine. J. Supercond. Novel Magn. 2013, 26, 1079-1083. [CrossRef]

22. Díaz, E.; Valle, M.B.; Barandiaran, J.M. Magnetic composite scaffolds of polycaprolactone/nFeHA, for bone-tissue engineering. Int. J. Polym. Mater. Polym. Biomater. 2016, 65, 593-600. [CrossRef]

23. Díaz, E.; Valle, M.B.; Ribeiro, S.; Lanceros-Mendez, S.; Barandiarán, J.M. Development of Magnetically Active Scaffolds for Bone Regeneration. Nanomaterials 2018, 8, 678. [CrossRef] [PubMed]

24. Bhowmick, A.; Pramanik, N.; Mitra, T.; Gnanamani, A.; Dasc, M.; Kundu, P.P. Synthesis, characterization and in vitro screening of a nano-hydroxyapatite/chitosan/Euryale ferox nanoensemble-An inimitable approach for bone tissue engineering. New. J. Chem. 2017, 41, 190-197. [CrossRef]

25. Aliramaji, S.; Zamanian, A.; Mozafari, M. Super-paramagnetic responsive silk fibroin/chitosan/magnetite scaffolds with tunable pore structures for bone tissue engineering applications. Mater. Sci. Eng. C 2017, 70, 736-744. [CrossRef]

26. Crescenzi, G.; Manzini, G.; Calzolari, G.; Borri, C. Nanocomposites of PLA and PCL based on montmorillonite and sepiolite. Eur. Polym. Mater. 1972, 8, 449. [CrossRef]

27. Cullity, B.D. Introduction to Magnetic Materials; EEUU; Addison-Wesley: Boston, MA, USA, 1972.

28. Es'haghi, Z.; Nezhadali, A.; Khatibi, A.D. Magnetically responsive polycaprolactone nanoparticles for progesterone screening in biological and environmental samples using gas chromatography. Anal. Bioanal. Chem. 2016, 408, 5537-5549. [CrossRef]

29. Bajpai, A.K.; Gupta, R. Synthesis and Characterization of Magnetite $\left(\mathrm{Fe}_{3} \mathrm{O}_{4}\right)$-Polyvivyl Alcohol-Based Nanocomposites and Study of Superparamagnetism. Polym. Compos. 2010, 31, 245-255. 
30. Motta, A.C.; Duek, E.A.R. Síntese, Caracterizagao e Degradagao “in vitro” do poli (L-ácido láctico-co-ácido glicólico). Matéria 2006, 11, 340-350.

31. Peña, J.; Corrales, T.; Izquierdo-Barba, I.; Doadrio, A.L.; Vallet-Regí, M. Long term degradation of poly (3-caprolactone) films in biologically related fluids. Polym. Degrad. Stab. 2006, 91, 1424-1432. [CrossRef]

32. Hua, F.J.; Park, T.G.; Lee, D.S. A facile preparation of highly interconnected macroporous poly (D,L-lactic acid-co-glycolic acid) PLGA scaffolds by liquid-liquid phase separation of a PLGA-dioxane-water ternary system. Polymer 2003, 44, 1911-1920. [CrossRef]

33. Ferrer, M.C.-H. Development and Characterisation of Completely Degradable Composite Tissue Engineering Scaffolds. PhD thesis, Universitat Politècnica de Catalunya, Barcelona, Spain, 2007.

34. Lu, L.; Peter, S.J.; Lyman, M.D.; Lai, H.L.; Leite, S.M.; Tamada, J.A.; Uyama, S.; Vacanti, J.P.; Langer, R.; Mikos, A.G. In vitro and in vivo degradation of porous poly (DL-lactic-coglycolic acid) foams. Biomaterials 2000, 21, 1837-1845. [CrossRef]

35. Hedberg, E.L.; Shih, C.K.; Lemoine, J.J.; Timmer, M.D.; Liebschner, M.A.K.; Jansen, J.A.; Mikos, A.G. In vitro degradation of porous poly (propylene fumarate)/poly (D.L-lactic-co-glycolic acid) composite scaffolds. Biomaterials 2005, 26, 3215-3255. [CrossRef] [PubMed]

36. You, X.; Zhou, S.; Zheng, X.; Xiao, Y.; Guo, T. Influence of in vitro Degradation of a Biodegradable Nanocomposite on Its Shape Memory Effect. J. Phys. Chem. C 2009, 113, 17630-17635. [CrossRef]

37. Kister, G.G.; Cassanas, G.; Vert, M. Effects of morphology, conformation and configuration on the IR and Raman spectra of various poly (lactic acids). Polymer 1998, 39, 267-273. [CrossRef]

38. Wu, F.; Liu, C.; O’Neill, B.; Wei, J.; Ngothai, Y. Fabrication and properties of porous scaffold of magnesium phosphate/polycaprolactone biocomposite for bone tissue engineering. Appl. Surf. Sci. 2012, 258, 7589-7595. [CrossRef]

39. Siddiqui, N.; Asawa, S.; Birru, B.; Baadhe, R.; Rao, S. PCL-Based Composite Scaffold Matrices for Tissue Engineering Applications. Mol. Biotechnol. 2018, 60, 506-532. [CrossRef]

40. Zhang, H.; Xia, J.; Pang, X.; Zhao, M.; Wang, B.; Yang, L.; Fu, S. Magnetic nanoparticle-loaded electrospun polymeric nanofibers for tissue engineering. Mater. Sci. Eng. C 2017, 73, 537-543. [CrossRef]

41. Brito-Pereira, R.; Correia, D.M.; Ribeiro, C.; Francesko, A.; Etxebarria, I.; Pérez-Álvarez, L.; Lanceros-Mendez, S. Silk fibroin-magnetic hybrid composite electrospun fibers for tissue engineering applications. Compos. Part B Eng. 2018, 141, 70-75. [CrossRef] 